\title{
Teaching Students About The Financial Crisis Through Best-Selling Books
}

Kristin Stowe, Wingate University, USA

Lisa A. Schwartz, Wingate University, USA

\begin{abstract}
The 2007-2009 financial crisis was such a momentous time that entire business courses could be devoted to its study. While some schools may undertake that task, this paper discusses ways in which students may learn about the crisis as part of an established course in economics or finance departments. Popular press books are highlighted, and writing prompts and discussion questions are shared. The paper focuses on the response by two key public institutions: the Federal Reserve and the Treasury. Results from a student survey provide evidence of value from the use of such books.
\end{abstract}

Keywords: Financial Crisis; Student Writing; Active Learning; Economics Education; Finance Education

\section{INTRODUCTION}

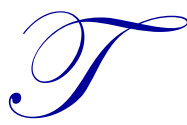

he years 2007 to 2009 were tumultuous for financial professionals. Much happened, from the main street mortgage mess, to the collapse of large commercial and investment banks, to the newfound roles of the Treasury and Federal Reserve. Bringing an understanding of these events into the classroom is necessary so that current students can better understand the crisis and its aftermath.

Given the number of significant events, some departments of economics and of finance may create courses dedicated to the study of the crisis. Other schools will incorporate the material into existing courses. Economics departments will likely use money \& banking classes, while finance departments will likely use financial institutions \& markets. Either way, a key objective is for students to understand the events and connections between them.

The literature shows that students benefit when faculty members actively engage students through the curriculum. Possibilities include movies, simulations, classroom experiments, and writing. For examples on related topics, Philpot and Oglesby (2005) utilized the movie It's a Wonderful Life as a case study on the management of a mutual financial institution. Tripp and Calvert (2007) incorporated a simulation to help students gain an experiential understanding of commercial bank management. Classroom experiments have engaged students in topics including inflation uncertainty, purchasing power parity, a firm's investment decisions and behavioral finance (Balyeat, 2008; Hazlett, 2007, 2008; Mitchell et al., 2009). Ideas on incorporating writing into economics and finance courses come from numerous sources including Krajicek (2008), Hershey (2007), Weber (2007), and Robertson, Bean and Peterson (2007). Students tend to provide favorable assessments of writing assignments (O'Neill, 2009). Belowaverage students are most likely to see higher exam scores as a result of papers (Olmsted \& Ruediger, 2013).

The discussion questions provided in this paper are a starting point for faculty members wishing to incorporate supplementary texts. Prompts are provided for In Fed We Trust and On the Brink. These books provide insight into the functioning during the crisis of the two most important public institutions (the Federal Reserve and the Treasury respectively). Through reading, students understand the concerns and thought-processes of key government officials. Students also gain a sense of the individual personalities of Mr. Paulson at the Treasury, Mr. Bernanke and Mr. Geithner at the Federal Reserve, and others. 


\section{DISCUSSION QUESTIONS}

\section{In Fed We Trust}

David Wessel, economics editor of the Wall Street Journal, conducted numerous interviews with Federal Reserve and Treasury staff members. The text highlights key decision makers at the Federal Reserve as they struggled with unprecedented events and as the power of the central bank grew. Table 1 provides a key quote from each chapter, along with discussion questions created by the authors of this paper for classroom use. The questions are designed to help students focus on the important information in each chapter and provide a template for classroom discussion on each chapter.

Table 1: In Fed We Trust

\begin{tabular}{|c|c|c|}
\hline Chapter & Select Quote & Discussion Questions/Writing Prompts \\
\hline Introduction & $\begin{array}{l}\text { "No one in a democracy, unelected, should have } \$ 800 \text { billion } \\
\text { to spend as he sees fit," [Barney Frank] said. The Great } \\
\text { Panic exposed the alchemy of central banking: the Fed could } \\
\text { create money from nothing. ( } p .7)\end{array}$ & \\
\hline $\begin{array}{l}\text { Chapter } 1 \text { - } \\
\text { Let Ol' Lehman Go }\end{array}$ & $\begin{array}{l}\text { But in what would prove a colossal mistake, [Paulson, } \\
\text { Geithner, and Bernanke] hadn't come prepared with a plan } \\
\text { to prevent a bankruptcy in case they couldn't sell Lehman as } \\
\text { they had managed to sell Bear Stearns. Once a sale proved } \\
\text { impossible, they were forced to scramble to explain why they } \\
\text { didn't do more. (pp. 21-22) }\end{array}$ & $\begin{array}{l}\text { 1. Compare the strategy taken by Mr. } \\
\text { Paulson during the negotiations surrounding } \\
\text { Lehman to the strategy taken by Mr. } \\
\text { Geithner. Why were these strategies } \\
\text { different? } \\
\text { 2. Describe the market reaction to Lehman's } \\
\text { failure. What was the role of systemic risk? } \\
\text { 3. Why did the Federal Reserve treat AIG } \\
\text { differently than Lehman? }\end{array}$ \\
\hline $\begin{array}{l}\text { Chapter } 2- \\
\text { Periodical Financial } \\
\text { Debauches }\end{array}$ & $\begin{array}{l}\text { Central banking was not simply a matter of turning valves to } \\
\text { regulate the flow of money, but also was about offering } \\
\text { reassurance and bolstering confidence, what Geithner called } \\
\text { "theater." (p. 35) }\end{array}$ & $\begin{array}{l}\text { 1. In the text, Mr. Wessel describes the panic } \\
\text { of } 1907 \text {. Compare and contrast the actions } \\
\text { taken by Mr. Morgan with the actions taken } \\
\text { by Mr. Bernanke during } 2008 \text {. } \\
\text { 2. Why does the author include historical } \\
\text { information? }\end{array}$ \\
\hline $\begin{array}{l}\text { Chapter } 3- \\
\text { Age of Delusion }\end{array}$ & $\begin{array}{l}\text { The causes of the Great Panic are many, the list of culprits } \\
\text { long. . . Blame the Federal Reserve, which was, after all, } \\
\text { created to head off financial panics. And, yes, blame Alan } \\
\text { Greenspan, who during his nineteen years at the helm had } \\
\text { created the Fed in his image. (p. 54) }\end{array}$ & $\begin{array}{l}\text { 1. Explain the four mistakes that Mr. } \\
\text { Greenspan is accused of making. }\end{array}$ \\
\hline $\begin{array}{l}\text { Chapter } 4- \\
\text { There are Jews in } \\
\text { Boston, Too }\end{array}$ & $\begin{array}{l}\text { Bernanke showed up as requested, sat down facing Card, } \\
\text { and heard him say: "How would you like to be Fed } \\
\text { chairman?" When he telephoned his wife with what he } \\
\text { considered to be good news, she burst into tears. She } \\
\text { realized, more than he did, that the job would be all- } \\
\text { consuming and change their lives. (pp. 83-84) }\end{array}$ & $\begin{array}{l}\text { 1. What is Mr. Bernanke's background? How } \\
\text { did his background prepare him to be } \\
\text { Chairman of the Federal Reserve? } \\
\text { 2. Describe the financial warning signs that } \\
\text { appeared during the summer of } 2007 \text {. }\end{array}$ \\
\hline $\begin{array}{l}\text { Chapter } 5- \\
\text { Pas de Deux }\end{array}$ & $\begin{array}{l}\text { At their August } 2007 \text { meeting, Fed officials discussed what } \\
\text { was going on in Europe. . . Bernanke was uneasy that } \\
\text { deteriorating financial markets might hurt the economy, and } \\
\text { so were Geithner and Mishkin. But no one used the word } \\
\text { crisis. (p. 99) }\end{array}$ & $\begin{array}{l}\text { 1. What events occurred in the global } \\
\text { financial markets? Why did these events } \\
\text { matter for the U.S. financial system? }\end{array}$ \\
\hline $\begin{array}{l}\text { Chapter } 6- \\
\text { The Four } \\
\text { Mouseketeers }\end{array}$ & $\begin{array}{l}\text { But within the Fed, confidence still ran high. No crisis was } \\
\text { unmanageable if you had the brainpower on hand to deal } \\
\text { with it, and the Fed had plenty of brains. (p. 106) }\end{array}$ & $\begin{array}{l}\text { 1. Consider Misters Kohn, Warsh, and } \\
\text { Geithner of the Federal Reserve. Which of } \\
\text { Mr. Bernanke's assistants served the role of } \\
\text { mediator? Diplomat? Networker? Explain. }\end{array}$ \\
\hline $\begin{array}{l}\text { Chapter } 7- \\
\text { Re: Re: Re: Re: Re: } \\
\text { Re: Blue Sky }\end{array}$ & $\begin{array}{l}\text { While they weren't facing runs, banks were increasingly } \\
\text { reluctant to lend to one another, and other parts of the } \\
\text { money markets were showing signs of malfunction. This was } \\
\text { threatening to freeze the pistons of the economy. (p. 116) }\end{array}$ & $\begin{array}{l}\text { 1. What actions did the Federal Reserve take } \\
\text { during August 2007? What concerns were } \\
\text { voiced? }\end{array}$ \\
\hline $\begin{array}{l}\text { Chapter } 8- \\
\text { Running from } \\
\text { Behind }\end{array}$ & $\begin{array}{l}\text { While economists on the outside worried that the Fed was } \\
\text { doing too little, some regional Fed bank presidents thought } \\
\text { Bernanke was doing too much... . . That internal divide } \\
\text { would plague Bernanke throughout the Great Panic, } \\
\text { particularly when the Fed began to devise new ways to lend } \\
\text { money. (pp. 129-130) }\end{array}$ & $\begin{array}{l}\text { 1. The Federal Reserve structure includes a } \\
\text { Board of Governors, } 12 \text { bank presidents and } \\
\text { the FOMC. According to traditional } \\
\text { textbook theory, what role does each play? } \\
\text { In the Great Panic, what role did each play? }\end{array}$ \\
\hline
\end{tabular}


Table 1 cont.

\begin{tabular}{|c|c|c|}
\hline $\begin{array}{l}\text { Chapter } 9 \text { - Unusual } \\
\text { and Exigent }\end{array}$ & $\begin{array}{l}\text { "This cost . . must be weighed against the effects on the } \\
\text { American economy and American financial system of } \\
\text { allowing this firm to collapse," Bernanke told a Senate } \\
\text { committee a few weeks after doing the Bear Stearns deal. By } \\
\text { then, anyone listening closely would have recognized the } \\
\text { chairman's mantra implicit in his testimony: whatever it } \\
\text { takes. (p. 173) }\end{array}$ & $\begin{array}{l}\text { 1. What does it mean for the Fed to do } \\
\text { something "unusual and exigent"? Provide } \\
\text { examples of Fed activities and the rationale } \\
\text { for them. } \\
\text { 2. Describe the negotiations that occurred } \\
\text { regarding Bear Stearns. What role did the } \\
\text { Federal Reserve play? The Treasury? }\end{array}$ \\
\hline $\begin{array}{l}\text { Chapter } 10- \\
\text { Fannie, Freddie, and } \\
\text { "Feddie" }\end{array}$ & $\begin{array}{l}\text { One mystery in August } 2008 \text { was why the U.S. economy was } \\
\text { doing as well as it was. ... Stanley Fischer, the Israeli } \\
\text { central banker and Bernanke's thesis advisor, offered three } \\
\text { alternative scenarios: Fiscal and monetary policy actions } \\
\text { had worked. The obvious financial mistakes of the recent } \\
\text { past weren't damaging to the economy. The worst was yet to } \\
\text { come. (p. } 185)\end{array}$ & $\begin{array}{l}\text { 1. Who are Fannie and Freddie? What role } \\
\text { did they play in the financial market? } \\
\text { 2. What role did the Federal Reserve play in } \\
\text { negotiations regarding Fannie and Freddie? } \\
\text { The Treasury? } \\
\text { 3. Describe the bazooka and the controversy } \\
\text { it created. }\end{array}$ \\
\hline $\begin{array}{l}\text { Chapter } 11- \\
\text { Breaking the Glass }\end{array}$ & $\begin{array}{l}\text { "It was becoming clear that the markets were going into } \\
\text { anaphylactic shock, and that we needed to do something," } \\
\text { Bernanke said. The Fed could no longer cope with the Great } \\
\text { Panic by itself. ( } p .199)\end{array}$ & $\begin{array}{l}\text { 1. Three prominent firms in the Great Panic } \\
\text { were Bear Stearns, Lehman Brothers, and } \\
\text { AIG. For each firm, identify the cause of its } \\
\text { failure. How was each firm treated by the } \\
\text { Federal Reserve and Treasury? } \\
\text { 2. September } 2008 \text { is the first time that the } \\
\text { Congress is asked to intervene in financial } \\
\text { markets. What political controversies arose? } \\
\text { 3. What role did the Federal Reserve play in } \\
\text { negotiations regarding legislation? The } \\
\text { Treasury? }\end{array}$ \\
\hline $\begin{array}{l}\text { Chapter } 12- \\
\text { Socialism with } \\
\text { American } \\
\text { Characteristics }\end{array}$ & $\begin{array}{l}\text { While Congress bickered, the Four Musketeers were } \\
\text { struggling to prevent the American financial system from } \\
\text { going under. With no master plan, the Fed - assisted by the } \\
\text { Treasury and bank regulators - continued to administer } \\
\text { emergency, experimental medicine to failing banks and } \\
\text { desperate markets. Whatever it takes. (p. 217) }\end{array}$ & $\begin{array}{l}\text { 1. Describe the negotiations over Wachovia. } \\
\text { In particular, what was the role of the FDIC? } \\
\text { What differences of opinion did FDIC } \\
\text { officials have with Federal Reserve and } \\
\text { Treasury officials? } \\
\text { 2. Why was Wells Fargo allowed to overrun } \\
\text { an existing deal that Citi had with Wachovia? } \\
\text { What did this reveal about the priorities of } \\
\text { FDIC officials? }\end{array}$ \\
\hline $\begin{array}{l}\text { Chapter } 13 \text { - World } \\
\text { of ZIRP }\end{array}$ & $\begin{array}{l}\text { Developing monetary policy for a weakened economy while } \\
\text { the federal funds rate hovered in ZIRP territory raised two } \\
\text { distinct sets of issues. One knot of questions clustered at the } \\
\text { intersection of ideology, economic theory and practicality: } \\
\text { How best to use the Fed's ability to print unlimited amounts } \\
\text { of money to compensate for the private players' } \\
\text { unwillingness or inability to provide credit? How best to } \\
\text { calibrate what the Fed was doing? The second issue was } \\
\text { turf, which, in Fed deliberations, went by the more dignified } \\
\text { term 'governance.' (p. 248) }\end{array}$ & $\begin{array}{l}\text { 1. Compare Bernanke's dashboard on } \\
\text { December } 11,2008 \text { to the starting values. } \\
\text { Which economic indicators have moved in a } \\
\text { positive direction? Which have moved in a } \\
\text { negative direction? What can be said about } \\
\text { the economy at this point? } \\
\text { 2. Explain ZIRP. What problem(s) does } \\
\text { ZIRP suggest? } \\
\text { 3. Describe the conflicts among Federal } \\
\text { Reserve officials. }\end{array}$ \\
\hline $\begin{array}{l}\text { Chapter } 14- \\
\text { Did Bernanke Keep } \\
\text { His Promise to } \\
\text { Milton Friedman? }\end{array}$ & $\begin{array}{l}\text { It may someday be said, with substantial accuracy, that after } \\
\text { some initial hesitation, Bernanke and his team did all they } \\
\text { could to defeat the Great Panic. But if the ultimate result is } \\
\text { years of painfully slow growth and widespread } \\
\text { unemployment, they will be judged by many Americans to } \\
\text { have failed. (p. } 266)\end{array}$ & $\begin{array}{l}\text { 1. Consider as a whole the actions by the } \\
\text { Federal Reserve during the Great Panic. Do } \\
\text { you think that these officials did a good job? } \\
\text { Why or why not? }\end{array}$ \\
\hline
\end{tabular}

\section{On the Brink}

Henry (Hank) M. Paulson, Jr. served as Secretary of the U.S. Treasury from 2006 to 2008. His understanding of the workings of Wall Street firms, gained while CEO of Goldman Sachs, proved invaluable. Paulson's memoir provides a largely chronological overview of events as they unfolded. Table 2 provides a key quote and ideas for discussion questions for each chapter. 
Table 2: On the Brink

\begin{tabular}{|c|c|c|}
\hline Chapter & Select Quote & Discussion Questions/Writing Prompts \\
\hline $\begin{array}{l}\text { Chapter } 1 \\
\text { (Thursday, } \\
\text { September 4, 2008) }\end{array}$ & $\begin{array}{l}\text { It is hard to exaggerate how central Fannie and Freddie were to } \\
\text { U.S. markets. Between them they owned or guaranteed more } \\
\text { than } \$ 5 \text { trillion in residential mortgages and mortgage-backed } \\
\text { securities - about half of all those in the country. To finance } \\
\text { operations, they were among the biggest issuers of debt in the } \\
\text { world: a total of about } \$ 1.7 \text { trillion for the pair. }(p .3)\end{array}$ & $\begin{array}{l}\text { 1. Who are Fannie Mae and Freddie } \\
\text { Mac? Explain what is happening to } \\
\text { Fannie and Freddie. }\end{array}$ \\
\hline $\begin{array}{l}\text { Chapter } 2 \text { (Sunday, } \\
\text { May } 28,2006 \text { ) }\end{array}$ & $\begin{array}{l}\text { I come from a line of strong women - smart, independent, plain- } \\
\text { spoken women. When my mother learned that President Bush } \\
\text { was going to nominate me to be Treasury secretary and that I } \\
\text { had agreed to take the job, she didn't mince words. 'You started } \\
\text { with Nixon and you're going to end with Bush?' she moaned. } \\
\text { 'Why would you do such a thing?' (p. 19) }\end{array}$ & $\begin{array}{l}\text { 1. Describe Mr. Paulson's background. } \\
\text { How did Mr. Paulson's background } \\
\text { prepare him to be Secretary of the } \\
\text { Treasury? }\end{array}$ \\
\hline $\begin{array}{l}\text { Chapter } 3 \\
\text { (Thursday, August } \\
\text { 17, 2006) }\end{array}$ & $\begin{array}{l}\text {.. The GSEs wielded incredible power on the Hill thanks in no } \\
\text { small part to their long history of employing - and enriching - } \\
\text { Washington insiders as they cycled in and out of government. } \\
\text { After accounting scandals had forced both GSEs to restate years } \\
\text { of earnings, their CEOs were booted, and House and Senate } \\
\text { efforts at reform broke down. (p. } 57)\end{array}$ & $\begin{array}{l}\text { 1. What is the role of the Treasury } \\
\text { Secretary on the Presidential leadership } \\
\text { team? }\end{array}$ \\
\hline $\begin{array}{l}\text { Chapter } 4 \\
\text { (Thursday, August } \\
9,2007 \text { ) }\end{array}$ & $\begin{array}{l}\text { The dangers for the U.S. economy had been obscured by an } \\
\text { unprecedented housing boom, fed in part by the low interest } \\
\text { rates that helped us recover from the downturn that followed the } \\
\text { bursting of the late-90's technology bubble and the impact of the } \\
9 / 11 \text { attacks. The housing bubble was driven by a big increase in } \\
\text { loans to less creditworthy, or subprime, borrowers that lifted } \\
\text { homeownership rates to historic levels. (p. } 64)\end{array}$ & $\begin{array}{l}\text { 1. What is happening in European } \\
\text { financial markets? } \\
\text { 2. Explain the historical mortgage } \\
\text { process and how the process changed } \\
\text { with the advent of securitization. } \\
\text { 3. How have the percentage of home } \\
\text { owners and the percentage of subprime } \\
\text { loans changed over time? How are these } \\
\text { changes related to securitization? } \\
\text { 4. What is a CDO? } \\
\text { 5. What is a SIV? Why is a SIV } \\
\text { considered "hidden leverage?" }\end{array}$ \\
\hline $\begin{array}{l}\text { Chapter } 5 \\
\text { (Thursday, March } \\
13 \text { - Sunday, March } \\
16,2008 \text { ) }\end{array}$ & $\begin{array}{l}\text { I've read through old newspaper reports and recently published } \\
\text { books about the Bear weekend. None of them quite captures our } \\
\text { race against time or how fortunate we were to have JPMorgan } \\
\text { emerge as a buyer that agreed to preserve Bear's economic } \\
\text { value by guaranteeing its trading obligations until the deal } \\
\text { closed. We knew we needed to sell the company because the } \\
\text { government had no power to put in capital to ensure the solvency } \\
\text { of an investment bank. ... (p. 121) }\end{array}$ & $\begin{array}{l}\text { 1. What is a CDS? } \\
\text { 2. Explain financial system } \\
\text { interconnectedness and how this creates } \\
\text { systemic risk. } \\
\text { 3. Explain how a loss of confidence can } \\
\text { create a self-fulfilling prophecy. } \\
\text { 4. Explain the events involving Bear } \\
\text { Stearns. What was the role of the } \\
\text { Treasury in this process? What was the } \\
\text { role of the Federal Reserve? }\end{array}$ \\
\hline $\begin{array}{l}\text { Chapter } 6 \\
\text { (Late March 2008) }\end{array}$ & $\begin{array}{l}\text { Among its main options, the government would get permission } \\
\text { from lawmakers to buy up to } \$ 500 \text { billion in illiquid mortgage- } \\
\text { backed securities from banks, freeing up their balance sheets and } \\
\text { encouraging lending. . . 'Break the Glass' also laid out the } \\
\text { possibility of taking equity stakes in banks to strengthen their } \\
\text { capital bases - though not as a first resort. (pp. 131-132) }\end{array}$ & $\begin{array}{l}\text { 1. What was the Break the Glass Band } \\
\text { Recapitalize Plan? Why was this plan } \\
\text { proposed? } \\
\text { 2. Discuss the situation at Lehman } \\
\text { Brothers. }\end{array}$ \\
\hline $\begin{array}{l}\text { Chapter } 7 \\
\text { (Saturday, July 12, } \\
\text { 2008) }\end{array}$ & $\begin{array}{l}\text { The next day they opened for business with new CEOs: Herb } \\
\text { Allison, former CEO of TIAA-CREF, at Fannie; and David } \\
\text { Moffett, former chief financial officer of U.S. Bancorp, at } \\
\text { Freddie. Treasury's administrative head, Peter McCarthy, } \\
\text { organized a remarkably smooth transition. Common } \\
\text { shareholders had lost nearly everything, but the government had } \\
\text { protected debt holders and buttressed each entity with } \$ 100 \\
\text { billion in capital and generous credit lines. }(p .170)\end{array}$ & $\begin{array}{l}\text { 1. Explain the special provisions } \\
\text { proposed for providing funding to GSE's. } \\
\text { Review the situation at Fannie and } \\
\text { Freddie (refer back to Chapter } 1 \text { for } \\
\text { additional details). }\end{array}$ \\
\hline $\begin{array}{l}\text { Chapter } 8 \text { (Monday, } \\
\text { September } 8 \text { - } \\
\text { Friday, September } \\
12,2008)\end{array}$ & $\begin{array}{l}\text { I could see that the CEOs weren't at all convinced that they } \\
\text { would solve anything by risking their own capital. No doubt, they } \\
\text { also questioned the government's resolve in saying we wouldn't } \\
\text { put any taxpayer money in. But it was also clear they had come } \\
\text { to the meeting with a purpose: they were committed to working } \\
\text { with us and wanted to find a solution that would avoid market } \\
\text { chaos. (p. 193) }\end{array}$ & $\begin{array}{l}\text { 1. What does the increase in CDS signal } \\
\text { to the market? } \\
\text { 2. Describe the events around Lehman } \\
\text { and the actions proposed to assist the } \\
\text { company. What was the market } \\
\text { solution? }\end{array}$ \\
\hline
\end{tabular}


Table 2 cont.

\begin{tabular}{|c|c|c|}
\hline $\begin{array}{l}\text { Chapter } 9 \\
\text { (Saturday, } \\
\text { September } 13 \text { - } \\
\text { Sunday, September } \\
14,2008)\end{array}$ & $\begin{array}{l}\text { After the Fed call, I heard the only good news of } \\
\text { the weekend: Bank of America was going to buy } \\
\text { Merrill Lynch for } \$ 50 \text { billion. Thain had managed } \\
\text { to arrange a sale at } \$ 29 \text { per share, a } 70 \text { percent } \\
\text { premium over Merrill's market price. I was } \\
\text { relieved: without this, I know, Merrill would not } \\
\text { have lasted the week. }(p .219)\end{array}$ & $\begin{array}{l}\text { 1. Explain the capital hole at Lehman and why it } \\
\text { impacted the bailout package. } \\
\text { 2. Explain the situation at AIG. Why is this company } \\
\text { important for the stability of the financial system? } \\
\text { 3. What role did government institutions play in the } \\
\text { collapse of Barclay's deal for Lehman? } \\
\text { 4. What were the anticipated risks for the rest of the } \\
\text { financial system of a Lehman bankruptcy? } \\
\text { 5. Explain the reasons that the situation at Lehman } \\
\text { differed from the situation at Bear Stearns. } \\
\text { 6. What is happening at AIG, Bank of America, and } \\
\text { Merrill Lynch? }\end{array}$ \\
\hline $\begin{array}{l}\text { Chapter } 10 \\
\text { (Monday, } \\
\text { September } 15 \text { - } \\
\text { Wednesday, } \\
\text { September } 17 \text {, } \\
\text { 2008) }\end{array}$ & $\begin{array}{l}\text { Shortly after I'd gotten off with Tim, my friend and } \\
\text { former Goldman colleague Ken Brody, now } \\
\text { chairman of Taconic Capital Advisors, reached } \\
\text { me. 'Hank, you made a big mistake,' he said. } \\
\text { 'This market is too fragile to handle a Lehman } \\
\text { Brothers bankruptcy. The system is on the verge } \\
\text { of collapse, and Morgan Stanley could well be } \\
\text { next.' (pp. 223-224.) }\end{array}$ & $\begin{array}{l}\text { 1. Discuss the situation unfolding in the financial } \\
\text { markets as Lehman news is released. } \\
\text { 2. For each of the following three markets, define the } \\
\text { asset and explain what happened as a result of } \\
\text { Lehman's failure: commercial paper, Treasuries, money } \\
\text { market funds. } \\
\text { 3. Why did Treasury and Federal Reserve officials view } \\
\text { AIG as different from Lehman? } \\
\text { 4. Explain the panic taking place across the entire } \\
\text { marketplace. How has the perception of systemic risk } \\
\text { changed? } \\
\text { 5. Discuss the proposed AIG solution. Were the } \\
\text { Treasury and Federal Reserve able to calm financial } \\
\text { markets? Why or why not? }\end{array}$ \\
\hline $\begin{array}{l}\text { Chapter } 11 \\
\text { (Thursday, } \\
\text { September } 18 \text { - } \\
\text { Sunday, September } \\
21,2008 \text { ) }\end{array}$ & $\begin{array}{l}\text { 'We need to buy hundreds of billions of dollars of } \\
\text { assets,' I said. I knew better than to utter the word } \\
\text { trillion. That would have caused cardiac arrest. } \\
\text { 'We need an announcement tonight to calm the } \\
\text { market, and legislation next week,' I said. (p. 261) }\end{array}$ & $\begin{array}{l}\text { 1. What was the Exchange Stabilization Fund? What } \\
\text { was the proposal to use the fund? } \\
\text { 2. Describe the proposed short selling ban. What } \\
\text { impact was it intended to have on the markets? } \\
\text { 3. Explain the proposal Mr. Paulson presented to deal } \\
\text { with bad assets of failing financial institutions. } \\
\text { 4. What was the Troubled Asset Relief Program } \\
\text { (TARP)? Why did Mr. Paulson believe the TARP was } \\
\text { so important to the financial system? } \\
\text { 5. What was happening at Morgan Stanley, Goldman } \\
\text { Sachs, Wachovia, and Washington Mutual? } \\
\text { 6. Why did Morgan Stanley and Goldman Sachs } \\
\text { become bank holding companies? }\end{array}$ \\
\hline $\begin{array}{l}\text { Chapter } 12 \\
\text { (Monday, } \\
\text { September } 22 \text { - } \\
\text { Thursday, } \\
\text { September 25, } \\
\text { 2008) }\end{array}$ & $\begin{array}{l}\text { Decorum started to evaporate as the meeting } \\
\text { broke into multiple side conversations with people } \\
\text { talking over each other. Shelby waved a sheaf of } \\
\text { papers, claiming they were from more than } 100 \\
\text { economists who all thought TARP was a bad idea. } \\
\text { He said we needed time to consider this plan. The } \\
\text { president jumped in to say, 'No, this is a situation } \\
\text { where we need to act. We don't have time to have } \\
\text { hearings with a bunch of economists.' (p. 298) }\end{array}$ & $\begin{array}{l}\text { 1. Discuss the political fight over TARP and why Mr. } \\
\text { Paulson felt so strongly that it was needed to stabilize } \\
\text { the financial markets. } \\
\text { 2. What happened to Washington Mutual? What was } \\
\text { the impact on the financial system? }\end{array}$ \\
\hline $\begin{array}{l}\text { Chapter } 13 \text { (Friday, } \\
\text { September } 26 \text { - } \\
\text { Friday, October } 3 \text {, } \\
\text { 2008) }\end{array}$ & $\begin{array}{l}\text { I explained that for the first time in U.S. history, } \\
\text { the government might have to invoke the imminent } \\
\text { danger of systemic risk to bail out a bank. By law, } \\
\text { the FDIC could provide financial assistance to } \\
\text { failing banks and thrifts as long as whatever } \\
\text { method it used - a loan, say, or a cash } \\
\text { contribution - cost less than outright liquidation. } \\
\text { (p. } 315)\end{array}$ & $\begin{array}{l}\text { 1. What was happening in the European/Global } \\
\text { financial markets? } \\
\text { 2. Why was deposit insurance such an important part of } \\
\text { the proposals to stabilize the financial system? What } \\
\text { changes were made to deposit insurance? } \\
\text { 3. Discuss the argument of imminent danger of } \\
\text { systemic risk as related to the Wachovia situation. } \\
\text { 4. Outline the proposals to save Wachovia. What was } \\
\text { the agreement with Citi? What was the Wells Fargo } \\
\text { proposal? Why did the FDIC allow the Wells Fargo } \\
\text { offer to supersede Citi's offer? } \\
\text { 5. How was TARP viewed by the markets? By the } \\
\text { Senate? Explain why there was so much disagreement } \\
\text { on TARP. }\end{array}$ \\
\hline
\end{tabular}


Table 2 cont.

\begin{tabular}{|c|c|c|}
\hline $\begin{array}{l}\text { Chapter } 14 \text { (Friday, } \\
\text { October } 3 \text { - } \\
\text { Monday, October } \\
13,2008 \text { ) }\end{array}$ & $\begin{array}{l}\text { I knew as well as anyone how this worked. Right } \\
\text { up until they failed, even the weakest banks } \\
\text { claimed that they didn't need capital. But the fact } \\
\text { was that in the midst of this crisis the market } \\
\text { questioned the balance sheets of even the strongest } \\
\text { banks, including Wells, which now owned } \\
\text { Wachovia with all of its toxic option ARMs. Our } \\
\text { banking system was massively undercapitalized, } \\
\text { though many banks did not want to acknowledge } \\
\text { it. Every bank in the room would benefit when we } \\
\text { restored confidence and stability. (p.365) }\end{array}$ & $\begin{array}{l}\text { 1. Did the passage of TARP stabilize the financial } \\
\text { system? Why or why not? } \\
\text { 2. What were the final details of CPP, how did it work } \\
\text { and who were the participants in the program? Why } \\
\text { was the program expected to help stabilize the financial } \\
\text { markets? } \\
\text { 3. What was the TLGP and how was it tied to CPP? } \\
\text { 4. What actions were taken by the U.S. Federal } \\
\text { Reserve, European Central Bank and Bank of England? } \\
\text { What precipitated the coordinated action? } \\
\text { 5. What was Warren Buffett's contribution to financial } \\
\text { solution and why was it important? }\end{array}$ \\
\hline $\begin{array}{l}\text { Chapter } 15 \\
\text { (Tuesday, October } \\
14,2008 \text { ) }\end{array}$ & $\begin{array}{l}\text { Between collapsing insurance giants, dying } \\
\text { shopping malls, bailed-out banks, and all-but- } \\
\text { bankrupt automakers, the American people had } \\
\text { watched one institution after another totter. ... I } \\
\text { began working hard on the speech I planned to } \\
\text { deliver on November } 12 \text { at Treasury, in which I } \\
\text { would make clear my decision to move away from } \\
\text { buying illiquid assets. (p. } 396)\end{array}$ & $\begin{array}{l}\text { 1. What was the market response to CPP? What was } \\
\text { the public response? } \\
\text { 2. What was the progress of TARP fund and payouts? } \\
\text { 3. What was the Fed's restructuring plan for AIG? }\end{array}$ \\
\hline $\begin{array}{l}\text { Chapter } 16 \\
\text { (Wednesday, } \\
\text { November } 19 \text { - Last } \\
\text { days in office) }\end{array}$ & $\begin{array}{l}\text { We needed to make another equity infusion in the } \\
\text { company. I believed that if we acted forcefully now } \\
\text { we had enough TARP capacity to prevent a Citi } \\
\text { failure. But if the market's confidence evaporated } \\
\text { and the giant bank had to start unwinding all of its } \\
\$ 3 \text { trillion in assets in a hurry, the losses could } \\
\text { spiral and shake the entire banking system down } \\
\text { to its smallest players. }(p .412)\end{array}$ & $\begin{array}{l}\text { 1. What was happening at Citi? Explain why Citi was } \\
\text { important to the markets. What was the final solution } \\
\text { for Citi? } \\
\text { 2. Why was the deal by Bank of America to buy Merrill } \\
\text { Lynch in jeopardy? What were the anticipated } \\
\text { consequences of failure? What was the final solution } \\
\text { for Bank of America? What was the role of the } \\
\text { Treasury in the process? } \\
\text { 3. How did the car companies become involved in the } \\
\text { financial crisis? What was the solution for the U.S. } \\
\text { automakers? What was the role of the Treasury in the } \\
\text { process? }\end{array}$ \\
\hline Afterword & $\begin{array}{l}\text { In a world where virtually everyone agrees we } \\
\text { have had inadequate regulation of banks and } \\
\text { capital markets, there is a very real danger that } \\
\text { financial regulation will become a wolf in sheep's } \\
\text { clothing, rivaling tariffs as the protectionist } \\
\text { measure of choice for those nations that want to } \\
\text { limit or eliminate competition. .. One of the } \\
\text { lessons of the Great Depression is that } \\
\text { protectionist actions by industrial nations seeking } \\
\text { to wall off their countries to protect their jobs and } \\
\text { industries were self-defeating and made that awful } \\
\text { downturn longer and more painful. }(p .451)\end{array}$ & $\begin{array}{l}\text { 1. Discuss the lessons Paulson lists as a result of the } \\
\text { financial crisis. }\end{array}$ \\
\hline
\end{tabular}

\section{Other Texts}

The two books discussed in this paper help students understand the federal response to the crisis. The texts do not cover all of the causes and consequences of the crisis. Faculty members wishing to focus on Wall Street trading, the development of securities markets, corporate culture, and/or the fate of the investment and commercial banks may wish to include books such as Banktown (Bank of America and Wachovia), House of Cards (Bear Stearns), The Colossal Failure of Common Sense (Lehman Brothers), Crash of the Titans (Merrill Lynch and Bank of America), and The Big Short (the market for credit default swaps). Table 3 provides a topical comparison of the books. 
Table 3: A Comparison of Content

\begin{tabular}{|c|c|c|c|c|c|c|c|}
\hline & $\begin{array}{c}\text { Cohan: House of } \\
\text { Cards }\end{array}$ & $\begin{array}{l}\text { Farrell: } \\
\text { Crash of } \\
\text { the Titans }\end{array}$ & $\begin{array}{c}\text { Lewis: } \\
\text { The Big } \\
\text { Short }\end{array}$ & $\begin{array}{c}\text { McDonald: } \\
\text { A Colossal } \\
\text { Failure }\end{array}$ & $\begin{array}{l}\text { Paulson: On } \\
\text { the Brink }\end{array}$ & $\begin{array}{l}\text { Rothacker: } \\
\text { Banktown }\end{array}$ & $\begin{array}{c}\text { Wessel: } \\
\text { In Fed } \\
\text { We Trust }\end{array}$ \\
\hline $\begin{array}{l}\text { Government policy } \\
\text { (CRA, Glass- } \\
\text { Stegall, CFMA) }\end{array}$ & $\mathrm{Ch} 25$ & & & Ch 3,7 & & & \\
\hline $\begin{array}{l}\text { Development of a } \\
\text { market for CDOs, } \\
\text { CDSs, etc }\end{array}$ & Ch 25,26 & & $\mathrm{Ch} 2,3$ & Ch 6 & & & \\
\hline $\begin{array}{l}\text { Trading desks, } \\
\text { trading strategy, } \\
\text { shorts }\end{array}$ & & Ch 1,2 & Ch 5 & Ch 6,10 & & & \\
\hline $\begin{array}{l}\text { Interbank financing, } \\
\text { repos, rollovers, risk } \\
\text { hedging }\end{array}$ & $\mathrm{Ch} 4,27$ & Ch 14 & Ch 9 & & & & \\
\hline $\begin{array}{l}\text { Corporate history } \\
\text { and culture; CEO } \\
\text { personalities }\end{array}$ & Ch $13-22,28$ & Ch $1-4,11$ & Ch 6 & Ch 9 & & Ch $1-5$ & \\
\hline Bear Stearns' failure & $\mathrm{Ch} 2,3,5-8,11,29$ & Ch 8 & Ch 10 & Ch 11 & Ch 5 & & Ch 9 \\
\hline Lehmann's failure & Epilogue & Ch 14 & Ch 10 & Ch 12 & Ch 8,9 & & Ch 1 \\
\hline $\begin{array}{l}\text { B of A's purchase of } \\
\text { Merrill Lynch }\end{array}$ & Epilogue & Ch 14-18 & & & Ch 9,16 & Ch $10,16-18$ & \\
\hline $\begin{array}{l}\text { Wachovia's growth } \\
\text { and collapse }\end{array}$ & & & & & Ch 11,13 & $\begin{array}{c}\text { Ch } 6,8,9, \\
11-15\end{array}$ & Ch 12 \\
\hline $\begin{array}{l}\text { AIG (Growth and } \\
\text { then bailout) }\end{array}$ & Epilogue & & Ch 3 & & Ch 10 & & Ch 11 \\
\hline $\begin{array}{l}\text { Federal Reserve - } \\
\text { Unusual and exigent } \\
\text { activities }\end{array}$ & Ch 9, Epilogue & & & & Ch 15 & & Ch 13 \\
\hline $\begin{array}{l}\text { Politics: The Fed, } \\
\text { Treasury and Wall } \\
\text { Street CEOs }\end{array}$ & & $\begin{array}{c}\text { Ch } 12,16, \\
17\end{array}$ & & Ch 12 & Ch 5,9 & $\begin{array}{c}\text { Ch } 13,14 \text {, } \\
17,20\end{array}$ & Ch 12 \\
\hline TARP & & & & & Ch $11,12,13$ & & Ch 11,12 \\
\hline Fannie \& Freddie & & & & & Ch 1,7 & & Ch 10 \\
\hline International banks & Ch 26, 29 & & & & $\mathrm{Ch} 4,14$ & & Ch 5 \\
\hline Epilogue & $\sqrt{ }$ & & $\sqrt{ }$ & $\sqrt{ }$ & $\sqrt{ }$ & $\sqrt{ }$ & (Ch 14) \\
\hline
\end{tabular}

Note: The chapters highlighted provide information on the topic listed. However, each chapter may contain other information. For example, Chapter 25 of House of Cards discusses government policy but is not exclusively about government policy.

\section{FINDINGS}

In Fed We Trust was utilized in a 300-level Money \& Financial Institutions class for three semesters. The average class size was 18 students. At the end of each semester, a student survey was distributed. The survey was administered during class time while the professor was out of the room. Completed surveys were held by the business school's secretary until after final grades were submitted. Students were guaranteed anonymity. While the sample size was small, the responses summarized in Table 4 indicate a positive assessment by students. It would be ideal have a control group of students for comparison; however, all of the sections taught utilized a supplementary text.

Table 4: Student Views of In Fed We Trust

\begin{tabular}{|c|c|c|}
\hline & Mean & Std. Dev \\
\hline 1. I have a better understanding of business-style writing after reading the book. & 3.92 & 0.80 \\
\hline 2. I have a better understanding of business-style writing after completing the assignment for each chapter. & 3.75 & 1.02 \\
\hline 3. I have a better understanding of the Great Panic after reading the book. & 4.65 & 0.59 \\
\hline 4. Class discussions helped me better understand the events in the book. & 4.28 & 0.73 \\
\hline $\begin{array}{l}\text { 5. I learned more about the Great Panic by reading and discussing the book than I would have if the professor } \\
\text { had lectured about the topic. }\end{array}$ & 3.75 & 0.91 \\
\hline 6. The book is appropriate for this finance course. & 4.37 & 0.75 \\
\hline 7. The book should be included in the course next year. & 4.12 & 0.97 \\
\hline
\end{tabular}

Note: $\mathrm{N}=51$ students. Answers were offered on a five point scale ranging from Strongly Agree (5) to Strongly Disagree (1). 
Students participated in weekly class discussions and completed weekly writing assignments based on the discussion prompts provided in this paper. Their work was used in evaluating whether students were meeting a departmental learning objective by demonstrating ability to prepare written reports and present information orally. Faculty could use the discussion questions as a basis for developing institutionally-appropriate assignments and rubrics for use in evaluating Assurance of Learning expectations regarding communication or discipline-specific knowledge.

\section{CONCLUSION}

As business professionals and academics look back, there is much to be learned about the causes of the crisis and the actions taken during the crisis. Popular press books written by insiders can provide valuable perspectives not usually found in academic texts. Student responses indicate that reading a supplementary text about the crisis and discussing the events are appropriate and useful. An unexpected benefit from this project was that we, as faculty members, gained new understanding of the workings of public institutions and financial markets through reading these books.

\section{AUTHOR INFORMATION}

Kristin Stowe is an associate professor of economics at Wingate University. She teaches a variety of courses, including money and banking. Her research interests include economics education, economic history, and financial economics. E-mail: kstowe@ wingate.edu (Corresponding author)

Lisa A. Schwartz, Wingate University, is a professor of finance. She is a past president of the Academy of Business Education. Her recent publications and research interests are in behavioral finance and finance education. E-mail: 1schwart@wingate.edu

\section{REFERENCES}

1. Bayleat, R. B. (2008). A class experiment: The dollar auction as a teaching tool to demonstrate the theories of behavioral finance. Advances in Financial Education, Winter, 136-146.

2. Cohan, W. D. (2010). House of cards: A tale of hubris and wretched excess on Wall Street. New York: Anchor Books.

3. Farrell, G. (2010). Crash of the titans. New York: Crown Publishing.

4. Hazlett, D. (2008). A classroom inflation uncertainty experiment. International Review of Economic Education, 7(1), 47-61.

5. Hazlett, D. (2007). A classroom investment coordination experiment. International Review of Economic Education, 6(1), 63-76.

6. Hershey, L. (2007). The 3D heuristic: A meta-teaching technique for improving business writing. Marketing Education Review, 17(1), 43-47.

7. Krajicek, J. (2008). Effective communication is 'hitched to everything in the (business) universe.' Business Communication Quarterly, September, 369-373.

8. Lewis, M. (2010). The big short: Inside the doomsday machine. New York: W. W. Norton \& Co.

9. McDonald, L., \& Robinson, P. (2009). A colossal failure of common sense: The inside story of the collapse of Lehman Brothers. New York: Crown Business.

10. Mitchell, D., Rebelein, R., Schneider, P., Simpson, N., \& Fisher, E. (2009). A classroom experiment on exchange rate determination with purchasing power parity. Journal of Economic Education, 40(2), 150-

165.

11. Olmsted, J., \& Ruediger, S. (2013). Using reflection papers in principles of macroeconomics classes. Journal of Economics and Economic Education Research, 14(1), 85-96.

12. O'Neill, P. (2009). On the use of writing assignments in intermediate microeconomic theory. American Journal of Business Education, 2(4), 25-36.

13. Philpot, J., \& Oglesby, R. (2005). It's a wonderful life: A case in financial institutions management and history. Journal of Financial Education, 31(Summer), 49-60. 
14. Paulson, H. M. (2010). On the brink: Inside the race to stop the collapse of the global financial system. New York: Business Plus.

15. Robertson, F., Bean, J., \& Peterson, D. (2007). Promoting high-level cognitive development: Bringing 'high bloom' into a financial institutions and markets class. Journal of Financial Education, Fall, 56-73.

16. Rothacker, R. (2010). Banktown: The rise and struggles of Charlotte's big banks. Winston-Salem: John F. Blair.

17. Weber, M. (2007). Teaching and reinforcing professional skills in the finance classroom. Advances in Financial Education, Spring, 1-28.

18. Wessel, D. (2009). In Fed we trust: Ben Bernanke's war on the great panic. New York: Crown Business. 
NOTES 